\title{
MEDIASI PIDANA (Penal Mediation) \\ DALAM PENYELESAIAN SENGKETAMASALAH PERBANKAN BERASPEK PIDANA DI LUAR PENGADILAN
}

\author{
Oleh : \\ Barda Nawawi Arief \\ Pengantar :
}

\begin{abstract}
Mediasi penal (penal mediation) soring juga disebut dengan berbagai istilah, antara lain : "mediation in criminal cases" atau "mediation in penal matters" yang dalam istilah Belanda disebut strabemiddeling, dalam istibh Jerman disebut "Dor Außergerichtiche Tatausgleich" (disingkat ATA") dan dalam istitah perancis disebut "de mediation pénale". Karena mediasi penal torutama mempertemukan antara pelaku tindak pidana dengan korban, maka mediasi penal ini sering juga dikenal dengan istitah "Victim-Offender Mediation" (VOM) atau Täter-OpferAusgleich (TOA).
\end{abstract}

1.Atternatif penyelesaian sengketa di luar pengadilan (yang biasa dikenal dengan istilah ADR atau "Alternative Dispute Resolution"), pada umumnya sering digunakan di lingkungan kasuskasus perdata, tidak untuk kasuskasus pidana. Dalam penyelesaian kasus pidana berdasarkan perundangundangan yang bertaku saat ini (hukum positif) pada prinsipnya tidak dapat diselesaikan di luar pengaditan, kecuali dalam hal-hal tertentu, antara lain :

a. Dalam hal delik yang dilakukan berupa "pelanggaran yang hanya diancam dengan pidana denda". Menurut Pasal 82 KUHP, kewenangan/hak menuntut delik pelanggaran itu hapus, apabila terdakwa telah membayar denda maksimum untuk delik pelanggaran itu dan biaya-biaya yang telah dikeluarkan kalau penuntutan telah dilakukan. Ketentuan dalam Pasal 82 KUHP ini dikenal dengan istilah "afkoop" atau "pembayaran denda damai" yang merupakan salah satu alasan penghapus penuntutan.'

\footnotetext{
${ }^{1}$ Dalam Konsep KUHP Baru (Psl. 145/2006) gugurnya kewenangan penuntutan telah diperluas, antata lain apabila : (d) ada penyelesaian di luar proses; (e) telah dibayatnya maksimum pidana denda untuk tindak pidana yang hanya diancam dengan pidana denda paling banyak kategori II; ( $($ ) telah dibayarnya maksimum pidana denda untak tindak pidana yang diancam dengan pidana penjata maksimum 1 tahun atau denda maksimum kategori III.
} 
b. Dalam hal tindak pidana dilakukan oleh anak di bawah usia 8 tahun. Menurut UU No. 3/1997 (Pengadilan Anak), batas usia anak nakal yang dapat diajukan ke pengadilan sekurang-kurangnya 8 tahun dan belum mencapai 18 tahun. Terhadap anak di bawah 8 tahun, penyidik dapat menyerahkan kembali anak tersebut kepada orang tua, wali, atau orang tua asuhnya apabila dipandang masih dapat dibina atau diserahkan kepada Departemen Sosial apabila dipandang tidak dapat lagi dibina oleh orang tua/wali/orang tua asuh (Pasal 5 UU No. 3/1997). 2.Walaupun pada umumnya penyelesaian sengketa di luar pengadilan hanya ada dalam sengketa perdata, namun dalam praktek sering juga kasus pidana diselesaikan di luar pengadilan melalui berbagai diskresi aparat penegak hukum atau melalui mekanisme musyawaraht perdamaian atau lembaga permaafan yang ada di dalam masyarakat (musyawarah keluarga; musyawarah desa; musyawarah adat dsb.). Praktek penyelesaian perkara pidana di luar pengadilan selama ini tidak ada landasan hukum formalnya, sehingga sering terjadi suatu kasus yang secara informal telah ada penyelesaian damai (walaupun melalui mekanisme hukum adat), namun tetap saja diproses ke pengadilan sesuai hukum yang berlaku.
3.Kondisi yang digambarkan di atas juga terjadi di banyak negara. Namun saat ini sudah terjadi perkembangan wacana dan bahkan perkembangan/ pembaharuan hukum di berbagai negara yang memberi kemungkinan penyelesaian kasus pidana di luar pengadilan melalui "mediasi pidana" yang dikenal dengan berbagai istilah sebagaimana telah dikemukakan di atas (lihat "Pengantar"). Adapun latar belakang pemikirannya ada yang dikaitkan dengan ide-ide pembaharuan hukum pidana (penal reform), dan ada yang dikaitkan dengan masalah pragmatisme. Latar belakang ide-ide "penal reform" itu antara lain ide pertindungan korban, ide hamonisasi, ide restorative justive, ide mengatasi kekakuan/formalitas dalam sistem yang berlaku, ide menghindari efek negatif dari sistem peradilan pidana dan sistem pemidanaan yang ada saat ini, khususnya dalam mencari altematif lain dari pidana penjara (altemative to imprisonment/attemative to custody) dsb. Latar belakang pragmatisme antara lain untuk mengurangi stagnasi atau penumpukan perkara, untuk penyederhanaan proses peradilan dsb. 4.Ide atau wacana dimasukkannya $A D R$ dalam penyelesaian perkara pidana, antara lain tertihat dari perkembangan sebagai berikut :

a.Dalam dokumen penunjang Kongres PBB ke-9/1995 yang berkaitan dengan 
manajemen peradilan pidana (yaitu dokumen A/CONF.169/6) diungkapkan perlunya semua negara mempertimbangkan "privatizing some law enforcement and justice functions" dan "altemative dispute resolution/ADR" (berupa mediasi, konsiliasi, restitusi, dan kompensasi) dalam sistem peradilan pidana. Khususnya mengenai ADR, dikemukan dalam dokumen itu sbb. : "The techniques of mediation, consiliation and arbitration, which have been developed in the civil law environment, may well be more widely applicable in criminal law. For example, it is possible that some of the serious problems that complex and lengthy cases involving fraud and whitecollar crime pose for courts could by reduced, if not entirely eliminated, by applying principles developed in conciliation and arbitration hearings. In particular, if the accused is a corporation or business entity rather than an individual person, the fundamental aim of the court hearing must be not to impose punishment but to achieve an outcome that is in the interest of society as a whole and to reduce the probability of recidivism".

Menurut kutipan di atas, ADR yang telah dikembangkan datam lingkungan hukum perdata, seyogyanya juga dapat diterapkan secara luas di bidang hukum pidana. Dicontohkan misalnya, untuk perkara-perkara pidana yang mengandung unsur "fraud" dan "white collarcrime" atau apabila terdakwanya adalah korporasi/ badan usaha. Ditegaskan pula, bahwa apabila terdakwanya adalah korporasibadan usaha, maka tujuan utama dari pemeriksaan pengadilan seharusnya tidaklah menjatuhkan pidana, tetapi mencapai suatu hasil yang bermanfaat bagi kepentingan masyarakat secara menyeluruh dan mengurangi kemungkinan terjadinya pengulangan (recidive).

b.Dalam laporan Kongres PBB ke-9/ 1995 tentang "The Prevention of Crime and the Treatment of Offenders" (dokumen ACONF.169/16), antara lain dikemukakan :

- untuk mengatasi problem kelebihan muatan (penumpukan perkara) di pengadilan, para peserta kongres menekankan pada upaya pelepasan bersyarat, mediasi, restilusi, dan kompensasi, khususnya untuk pelaku pemula dan pelaku muda (dalam laporan No.112);

- Ms. Toulemonde (Menteri Kehakiman Perancis) mengemukakan "mediasi penal" (penal mediation) sebagai suatu alternatif penuntutan yang memberikan kemungkinan 
penyelesaian negosiasi antara pelaku tindak pidana dengan korban. (dalam laporan No. 319); c.Dalam Deklarasi Wina, Kongres PBB ke-10/2000 (dokumen A/ CONF.187/ 4/Rev.3), antara lain dikemukakan bahwa unluk memberikan perlindungan kepada korban kejahatan, hendaknya diintrodusir mekanisme mediasi dan peradilan restorati (restorative justice). d.Dalam "International Penal Reform Conference" yang diselenggarakan di Royal Holloway College, Universily of London, pada langgal 13-17 April 1999 dikemukakan, bahwa salah satu unsur kunci dari agenda baru pembaharuan hukum pidana (the key elements of a new agenda for penal reform) lalah perlunya memperkaya sistem peradilan formal dengan sistem atau mekanisme informal dalam penyelesaian sengketa yang sesuai dengan standar-standar hak asasi manusia (the need to enrich the formal judicial system with informal, locally based, dispute resolution mechanisms which meet human rights standards). Konferensi ini juga mengidentikasikan sembian strategi pengembangan dalam melakukan pembaharuan hukum pidana, yailu mengembangkan membangun :

1.Resloralive juslice

2.Altemative dispule resolution

3.infomal justice

\section{Alternatives to Custody}

5.Altemative ways of dealing with juveniles

6.Dealing wilh Violent crime

7.Reducing the prison population

8. The Proper Management of Frisons

9.The role of civil sociely in penal refom

c.Pada 15 September 1999, Komisi

Para Menteri Dewan Eropa the Committee of Ministers of the Council of Europe) telah menerima Recommendation No. R (99) 19 tentang "Mediation in Penal Matters".

f. Pada 15 Maret 2001, Uni Eropa juga mengikuti dengan membuat the EU Councl Framewok Decision benang "kedudukan korban di dalam proses pidana" (the Standing of Victims in Criminal Proceedings) - EU (2001/ 220/JBZ) yang di dalamnya termasuk juga masalah mediasi. Pasal $\uparrow$ (e) dari Framework Decision ini mendeinisikan "mediation in criminal cases" sebagai : "the search prior to or during criminal proceedings, for a negotiated solution between the victim and the author of the offence, mediated by a competent person'. Pasal 10nya menyatakan, setiap negara anggola akan bensaha "to promote mediation in criminal cases for offences which it considers approprate for this sort of measure". Walaupun Pasal 10 ini

2 Annemieke Wolthuis, Will Mediation in Penal Matters be mandatary? The Impact of International 
terkesan hanya memberi dorongan (encourage ment), namun menurut Annemieke Wolthuis ${ }^{2}$, berdasarkan penjelasan di dalam website Uni Eropa, negara anggota wajib mengubah UU dan hukum acara pidananya, antara lain mengenai "the right to mediation".

g.Pada tanggal 24 Juli 2002, Ecosoc (PBB) telah menerima Resolusi 2002/12 mengenai "Basic Principles on the Use of Restorative Justice Programmes in Criminal Matters" yang di dalamnya juga mencakup masalah mediasi. ${ }^{3}$

Resume :

- Masalah mediasi dalam perkara pidana, sudah masuk dalam agenda pembahasan di tingkat internasional, yaitu dalam Kongres PBB ke-9/1995 dan ke-10/2000 mengenai "Prevention of Crime and the Treatment of Offenders" dan dalam Konferensi Intemasional Pembaharuan Hukum Pidana (International Penal Reform Conference) tahun 1999;

- Pertemuan-pertemuan intemasional itu mendorong munculnya tiga dokumen internasional yang berkaitan dengan masalah peradilan restoratif dan mediasi dalam perkara pidana, yaitu : (1)

Standards, fp.enter.net/ restorativepractices/ MediationMandatory the Recommendation of the Council of Europe 1999 No. R (99) 19 tentang "Mediation in Penal Matters"; (2) the EU Framework Decision 2001 tentang the Standing of Victims in Criminal Proceedings; dan (3) the UN Principles 2002 (draft Ecosoc) tentang "Basic Principles on the Use of Restorative Justice Programmes in Criminal Matters";

- Dari berbagai dokumen internasional itu, masalah "penal mediation" tidak muncul sebagai masalah yang berdiri sendiri, tetapi berkaitan dengan latar belakang ide "penal reform", "restorative justice", "alternative to imprison ment/custody", masalah "perlindungan korban" dan untuk mengatasi problem penumpukan perkara ("the problems of court case overload").

Catatan :

Upaya untuk mengurangi beban pengadilan (penumpukan perkara), di beberapa negara lain juga ditempuh dengan dibuatnya

\footnotetext{
${ }^{3}$ Tercantum dalam dolumen E/2002/INF/2/ Add.2, international-research-project-report2 (sbr.: internet); lihat juga Annemieke, ibid.

*) Menurut Psl. 248 KUHAP Jepang, penuntutan tidak perlu dilakukan setelah mempertimbangkan faktor- faktor: (a) karakter, usia dan keadaan si pelaku; (b) bobot keseriusan tindak pidana dan keadaankeadaan pada saat delik itu dilakukan; (c)
} 
ketentuan mengenai "penundaan penuntutan" ("suspension of prosecution") atau "penghentian/ penundaan bersyarat" ("conditional dismissal/discontinuance of the proceedings") walaupun bukti-bukti sudah cukup, seperti diatur dalam Pasal 248 KUHAP (Hukum Acara Pidana) Jepang "l dan Pasal 27-29 KUHP (Hukum Pidana Materiel) Polandia "?.

5. Khususnya mengenai pengaturan "penal mediation" di beberapa negara, dapat dikemukakan bahan komparasi sebagai berikut :-

a. AUSTRIA :

- Pada bulan February 1999 parlemen Austria menerima amandemen terhadap KUHAP mengenai "refrainment from prosecution, non-judicial mediation and diversion" (Strciprozeßnovelle 1999) yang diberlakukan pada Januari 2000 .

- Pada mulanya diversi penuntutan hanyo untuk anak melalui ATAJ

keadaan-keadaan yang diakibatkan oleh tindak pidana itu. Lihat Barda Nawawi Arief, Kebijakan Legislatif dalam Penanggulangan Kejabatan dengan Pidana Penjara, BP UNDIP. Semarang, cetakan ke-3, 2000, hal. 169.

*) Menurut Psl. 27 KUHP Polandia, penuntutan pidana dapat dihentikan apabila : (1) tingkat bahaya sosial dari perbuatan itu tidak besar, (2) keadaan-keadaan sekitar dilakukannya perbuatan itu tidak menimbulkan kesangsian; (3) si pelanggara sébelumnya tidak pernah dipidana; (4) dari sikap/karakter pribadi dan riwayat hidup si pelanggar dapat diperkirakan, bahwa meskipun penuntutan ditunda, ia akan
(Außergerichtlicher Tatausgleich für Jugendliche), namun kemudian bisa juga untuk orang dewasa melalui ATAE (Außergenichticher Tatausgleich für Erwachsene) yang merupakan bentuk "victimoffender mediation" (NOM). b.BELGIA :

- Pada tahun 1994 diberlakukan UU tentang mediasipenal (the Act on Penal Mediation) yang juga disertai dengan pedomannya (the Guideline on Penal Mediation). Tujuan utama diadakannya "penal mediation" ini adalah untuk memperbaiki kerugian materiel dan moral yang ditimbulkan karena adanya tindak pidana. Namun, mediasi juga dapal dilakukan agar sipelaku melakukan statu terapy atau melakukan kerja sosial (community service).

- Dengan adanya ketentuan ini, penuntut umum diberi kebebasan yang lebih has untuk memprioritaskan kepentingan korban. Apabila petaku tindak pidans berjani untuk memberi kompensasi atau

tetap menghormati tertib hukum dan khususnya tidak akan melakukan pelanggaran lagi. Menurut Psl. 28 (2), selama proses penuntutan dihentikan terdakwa dapat diwajibkan ; (1) mempedrbaiki kerugian yang ditimbulkan; (2) minta maaf kepada korban; (3) melakukan pekerjaan tertentu untuk tujuan sosial. Lihat Barda Nawawi Arief, ibid., hal. 171. ${ }^{4} \mathrm{Sub}$ a s/d d, disarikan dari Brienen, M.E.I. and E.H. Hoegen (2000), Victims of Crime in 22 European Criminal Justice Systems: The Implementation of Recommendation (85) 11 of the Conncil of Europe on the Position of the Victim in the Framezure of Criminal Law and Procedure. Dissertation, University of Tilburg. Nijmegen, 
telah membei kompensasi kepada korban, maka kasusnya dapat tidak diteruskan ke penuntutan. Pada mulanya kewenangan penuntut umum untuk tidak meneruskan penuntutan karena adanya pembayaran kompensasi hanya untuk delik yang diancam maksimum 5 tahun penjara, tetapi dengan adanya ketentuan baru ini, dapat digunakan juga untuk delik yang diancam pidana maksimum 2 tahun penjara.

\section{c.JERMAN}

- Pada tahun 1994, ditambahkan Pasal 46a ke dalam StGB (KUHP). Pasal ini menetapkan, bahwa apabila pelaku memberi ganti rugi/kompensasi kepada korban secara penuh atau sebagian besar, maka pidananya dapat dikurangi atau bahkan dapat dibebaskan dari pemidanaan. Pembebasan pidana hanya dapat diberikan apabila deliknya diancam dengan maksimum pidana 1 tahun penjara atau 360 unit denda harian.

- Penyelesaian kasus pidana antara pelaku dan korban melalui kompensasi ini dikenal dengan istilah Täter-OpferAusgleich (TOA). Apabila TOA telah dilakukan, maka penuntutan dihentikan (s. 153b StPOI Strafprozessordnung/ KUHAP).

d.PERANCIS :

- Pada tahun 1993, UU mengizinkan penuntut umum untuk melakukan mediasi antara pelaku dengan korban, sebelum mengambil keputusan dituntut tidaknya seseorang. Apabila mediasi tidak berhasil dilakukan, penuntutan baru dilakukan; namun apabila berhasil penuntutan dihentikan (s. 41 CCP).

- Untuk kejahatan-kejahatan tertentu, Pasal 41-2 CCP membolehkan penuntut umum meminta pelaku untuk memberi kompensasi kepada korban, daripada mengenakan pidana denda, mencabut SIM, atau memerintahkan sanksi alternatif berupa pidana kerja sosial selama 60 jam.

e.POLANDIA : ${ }^{5}$

- Proses mediasi perkara pidana diatur dalam Pasal 23a CCP (Code of Criminal Procedure) dan Peraturan Menteri Kehakiman 13 Juni 2003 tentang "Mediation proceedings in criminal matters" (Journal of Laws No 108, item 1020). Pengadilan dan jaksa, atas inisiatifnya atau atas persetujuan korban dan pelaku, dapat menyerahkan suatu kasus ke lembaga terpercaya atau seseorang untuk melakukan mediasi antara korban dan terdakwa. Proses mediasi paling lama satu bulan. Biaya proses mediasi ditanggung oleh perbendaharaan negara (State Treasury).

- Mediator melakukan kontak dengan para pihak, merancang pertemuan para pihak, membantu merumuskan materi kesepakatan, dan mengawasi terpenuhinya kewajiban yang timbul dari kesepakatan itu. Mediator kemudian melaporkan semuanya itu kepada

The Netherlands: Wolf Legal Productions (WLP) ISBN 90-5850-004-7 
pengadilan/jaksa. Hasil positif dari mediasi itu menjadi alasan untuk tidak melanjutkan proses pidana.

Dari uraian di atas dapat diidentifikasikan, bahwa :

- mediasi sebagai salah satu bentuk ADR dimungkinkan dalam perkara pidana; namun tetap diberi payung/kerangka hukum (mediation within the framework of criminal law), yang bisa diintegrasikan dalam hukum pidana materiel (KUHP) atau hukum pidana formal (KUHAP).

6. Mediasi pidana yang diungkapkan di atas, bertolak dari ide dan prinsip kerja sebagai berikut : ${ }^{6}$

a. Penanganan konflik (Conflict Handling/ Konfliktbearbeitung):

Tugas mediator adalah membuat para pihak melupakan kerangka hukum dan mendorong mereka teribat dalam proses komunikasi. Hal ini didasarkan pada ide, bahwa kejahatan telah menimbulkan konflik interpersonal. Konflik itulah yang dituju oleh proses mediasi.

b. Berorientasi pada proses (Process Orientation - Prozessorientierung):

http: / / ec.europa.eu/civiljustice / adr/ adr_pol en.htm

6 Stefanie Tränkle, The Tension between Judicial Control and Autonomy in Victim-Offender Mediation - a Microsociological Study of a Paradoxical Procedure Based on Examples of the Mediation Process in
Mediasi penal lebih berorientasi pada kualitas proses daripada hasil, yaitu : menyadarkan pelaku tindak pidana akan kesalahannya, kebutuhankebutuhan konflik terpecahkan, ketenangan korban dari rasa takut dsb.

c. Proses informal (Informal ProceedingInformalität):

Mediasi penal merupakan suatu proses yang informal, tidak bersifat birokratis, menghindari prosedur hukum yang ketat.

d. Ada partisipasi aktif dan otonom para pihak (Active and Autonomous Participation - Parteiautonomie/ Subjektivierung)

Para pihak (pelaku dan korban) tidak dilihat sebagai objek dari prosedur hukum pidana, tetapi lebih sebagai subjek yang mempunyai tanggungjawab pribadi dan kemampuan untuk berbuat. Mereka diharapkan berbuat atas kehendaknya sendiri.

7. Model-model Mediasi Pidana : Dalam "Explanatory memorandum" dari Rekomendai Dewan Eropa No. $R$ (99) 19 tentang "Mediation in Penal Matters", dikemukakan beberapa model mediasi penal sebagai berikut:

a. "informal mediation"

b. "Traditional village or tribal moots"

c. "victim-offender mediation" 
d. "Reparation negotiation programmes"

e. "Community panels or courts"

f. "Family and community group conferences",

Ad (a) : Model "informal mediation"

* Model ini dilaksanakan oleh personil peradilan pidana (criminal justice personnel) dalam tugas normalnya, yaitu dapat dilakukan oleh JPU (Jaksa Penuntut Umum) dengan mengundang para pihak untuk melakukan penyelesaian informal dengan tujuan, tidak melanjutkan penuntutan apabila tercapai kesepakatan; dapat dilakukan oleh pekerja sosial atau pejabat pengawas (probation officer), oleh pejabat polisi, atau oleh Hakim.

* Jenis intervensi informal ini sudah biasa dalam selunh sistem hukum.

Ad (b) : Model "Traditional village or tribal moots"

Menurut model ini, seluruh masyarakat bertemu untuk memecahkan konflik kejahatan di antara warganya.

- Model ini ada di beberapa negara yang kurang maju dan di wilayah pedesaan/pedalaman.

- Model ini lebih memilih keuntungan bagi masyarakat luas.

- Model ini mendahului hukum barat dan telah memberi inspirasi bagi kebanyakan program-program mediasi modern. Program mediasi modern sering mencoba memperkenalkan berbagai keuntungan dari pertemuan suku (tribal moots) dalam bentuk yang disesuaikan dengan struktur masyarakat modern dan hak-hak individu yang diakui menurut hukum.

Ad (c) : Model "victim-offender mediation"

- Mediasi antara korban dan pelaku merupakan model yang paling sering ada dalam pikiran orang.

- Model ini melibatkan berbagai pihak yang bertemu dengan dihadiri oleh mediator yang ditunjuk. Banyak variasi dari model ini. Mediatomya dapat berasal dari pejabat formal, mediator independen, atau kombinasi.

- Mediasi ini dapat diadakan pada setiap tahapan proses, baik pada tahap kebijaksanaan polisi, tahap penuntutan, tahap pemidanaan atau setelah pemidanaan.

- Model ini ada yang diterapkan untuk semua tipe pelaku tindak pidana; ada yang khusus untuk anak; ada yang untuk tipe tindak pidana tertentu (misal pengutilan, perampokan dan tindak kekerasan). Ada yang terutama ditujukan pada pelaku anak, pelaku pemula, namun ada juga untuk delik-delik berat dan bahkan untuk recidivist. 
Ad (d) : Model "Reparation negotiation programmes"

- Model ini semata-mata untuk menaksir/menilai kompensasi atau perbaikan yang hanus dibayar oleh pelaku tindak pidana kepada korban, biasanya pada saat pemeriksaan di pengadilan.

- Program ini tidak berhubungan dengan rekonsiliasi antara para pihak, tetapi hanya berkaitan dengan perencanaan petbaikan materiel.

- Dalam model ini, pelaku windak pidana dapat dikenakan program keja agar dapat menyimpan vang untuk membayar gantỉ rugi/ komenesasi.

Ad (e) : Model "Community panels or courts"

- Model ini menupakan program

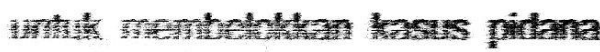
dari penuntutan atau peradilan pada posedir masyankat yand lebih lloksibel dan informal dan seing mothatkan unsur meriasi atau negosiasi.

Ad (1): Model "Family and commentivy group conferences"

- Model ini telah dikembangkan di Australia dan New Zealand, yang melibatkan partisipasi masyaraka! dalam SPP (sistem peradilan pidana). Tidak hanya melibatkan korban dan pelaku tindak pidana, tetapi juga keluarga pelaku dan warga masyarakat lainnya, pejabat tertentu (seperti polisi dan hakim anak) dan para pendukung korban.

- Pelaku dan keluarganya diharapkan menghasilkan kesepakatan yang komprehensif dan memuaskan korban serta dapat membantu untuk menjaga sipelaku keluar dari kesusahan/persoalan berikutnya.

8. Mediasi pidanatpenal dalam kasus perbankan :

- Tolah dikemukakan di alas, bohwa menurut hukum yang berlaku saat ini thukum posith, pade prinsthye perkara pidana tidak dapat

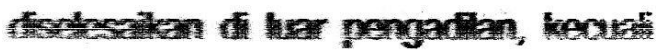
dalam "pelanggaran yang hanya dancam pidana denda" dan dalom kasus "anak nakal di bawah 8 tahn" yang melakuken indak pidana. Ketentuan ini sebenamya tidak

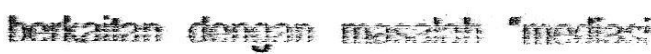
pidana" yang menjadi topik bahasan, kususwya cklam masakh perbankan.

- Kasus yang dipermasalahkan dalam

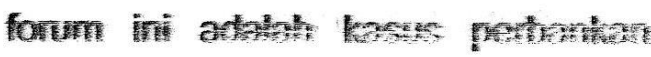
yang mengandung aspek pidana, antara bin - masalah transfer dana nasabah kepada pihak bin akibat

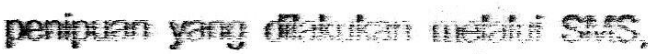
dan pembobolan rekening nasabah bank melalui ATM. Dalam kasus ini, yang dipermasalahkan atckat

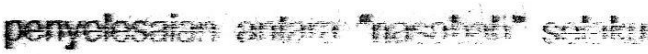


Jurnal Law Reform

Volume 2, Nomor 1, Tahun 2006
Program Studi Magister Ilmu Hukum Fakultas Hukum Universitas Diponegoro korban dengan pihak Bank. Kalau terhadap masalah ini akan diselesaikan oleh pihak Bank dengan jalan mediasi, maka sebenarnya hal ini tidak termasuk "mediasi pidana" yang ciricirinya telah diuraikan di atas. Mungkin lebih tepat disebut "mediasi perbankan".

- Masalah "transfer dana yang kelitu akibat penipuan SMS" dan "pembobolan rekening nasabah bank melalui ATM memang terkesan mengandung masalah pidana. Namun proses pidana dapat berialan apabila pelakunya dapat dndentinasikan, ditangkap dan diproses. Apabila peiakunya tidak jelas atau tidak teridentifikasi, maka proses pidana mengalami kesultian. Namun permasalahan utamanya bukan pada proses pidana temadap sipelaku, tetapi masalah kerugian yang timbul pada phak kotban. Apakan pelaku dapat diproses pidana ateu tidak, bagl korban mungkin tidak begitu masalah. Yang jelas masalahnya bagi korban adaian, bahwa dia sudah mengalami "keruglan".

- Karena masalan di atas suili diselesaikan melalui proses pidana (karena pelaku tinciak pidana ticiak terdeteksi). maka periu dicankan solusinya, antara lain : (a) melaiui mediasi perbankan; atau (b) melaiui mediasi penal Namun nampaknya masih banyak masalah/kendala, antara lain masalah "payung hukumnya".

- Menurut Peraturan Bank Indonesia (PBI) No. 8/5/PBI/2006 tentang "Mediasi Perbankan", mediasi yang dapat dilakukan terbatas pada sengketa yang memiliki nilai tuntutan finansial maksimum sebesar Rp. $500.000 .000,00$ (lima ratus juta rupiah). Dalam Surat Edaran Bank indonesia No. 8/14/DPNP 1 Juni 2006 ditegaskan lagi, bahwa sengketa itu merupakan sengketa keperdataan yang timbul dari transaksi keuangan. Jadi terbatas hanya pada masalah perdata. Sekiranya masaloh di atas (vang beraspek masaiah pidana) juga akan dicakup dalam medias perbankan, seyogyanya ruang ingkup kewenangan tu ditegaskan secara eksphsit, knususnya mencakup masalah pembobolan rekening nasabah bank melalu ATM. Kewenangan eksplisit itu misainya ditegaskan dalam ruang lingkup kewenangan Banking Mediation Bureau (Bivib) di Mialaysia, yang antara lain dapat menangani sengketa bernilai RM 25,000 , akibat penarikan ATM yang tidak sah (Unauthorised Automatic Telier Machine withorawais) atau akibat penggunaan kartu kredit

Germany and France, hto:ll 
yang tidak sah (Unauthorised use of credit cards) ${ }^{7}$.

- Sehubungan dengan pertanggungjawaban penerbit kartu kredit, Dewan Gebernur Bank Latvia (Bank of Latvia Board of Governors) dalam resolusinya No. $89 / 9$ tanggal 13 September 2001 tentang "Recommendations for Transactions Effected by Means of Electronic Payment Instruments" menyatakan sebagai berikut: $^{8}$

4.4.4 The issuer shall be liable to the holder of an electronic money instrument for the lost amount of value stored on the instrument and for the defective execution of the holder's transactions, where the loss or defective execution is attributable to a malfunction of the instrument, of the device/terminal or any other equipment authorized for use. If the malfunction was caused by the holder knowingly or in breach of Article 3.1.3.1, the issuer shall not be liable for the lost amount of value stored on the instrument and for the defective execution of the holder's transactions.

traenkle_e.html.
Inti dari ketentuan di atas ialah, bahwa penerbit instrumen pembayaran elektronik ("The Issuer" : a credit institution that makes an electronic payment instrument) bertanggungjawab terhadap pemilik instrumen atas hilangnya nilai (uang) yang tersimpan dalam instrumen itu dan terhadap rusaknya pelaksanaan transaksi yang dilakukan sipemilik, apabila hal itu disebabkan oleh tidak berfungsinya instrumen itu, tidak berfungsinya peralatan/ terminal pembayaran, atau tidak berfungsinya peralatan lain yang sah untuk digunakan. Apabila tidak berfungsinya itu disebabkan oleh kesalahan sipemilik sendiri, pihak penerbit tidak bertanggung jawab.

$$
-\infty 00-
$$

Sumber Bacaan :

- A New Agenda for Penal Reform, Intemational Penal Reform Conference 13-17 APRIL 1999, Royal Holloway College, University of London, Egham, Surrey, United Kingdom

- Alternative dispute resolutions - Poland http:// ec.europa.eu/civiljustice/ adr/adr pol_en.htm

Annemieke Wolthuis, Will Mediation in Penal Matters be mandatory? The Impact of International Standards, fp.enter.net/restorativepractices/Mediation Mandatory 
- Brienen, M.E.I. and E.H. Hoegen (2000), Victims of Crime in 22 European Criminal Justice Systems: The Implementation of Recommendation (85) 11 of the Council of Europe on the Position of the Victim in the Framework of Criminal Law and Procedure, Dissertation, University of Tilburg. Nijmegen, The Netherlands: Wolf Legal Productions (WLP) ISBN 905850-004-7

- international-research-project-report2 (sbr.: internet);

- Lee Swee Seng, Mediation: Its Practice\& Procedure, uww.leesweeseng.com/mediation.ppt

- Mediation in Penal Matters, (sbr internet).

- Peraturan Bank Indonesia No: 8/5/ PBI/2006 Tentang Mediasi Perbankan.

- Report of the Ninth UN Congress on the Prevention of Crime and the Treatment of Offenders, Cairo, 29 April - 8 May 1995, ACCONF.169/16 12 May 1995.

- Stefanie Tränkle, The Tension between Judicial Control and Autonomy in Victim-Offender Mediation a Microsociological Study of a Paradoxical Procedure Based on Examples of the Mediation Process in Germany and France, http:// Www.iuscrim.mpg.de/forsch/krim/ traenkle_e.html.

- Surat Edaran Bank Indonesia No. 8/14/DPNP, 1 Juni 2006.

the $10^{\text {th }}$ UN Congress on the Prevention of Crime and the Treatment of Offenders, Vienna Declaration on Crime and Justice: Meeting the Challenges of the Twentyfirst Century, AVCONF.187/4/Rev.3.

- the Bank of Latvia Board of Governors, Resolution No. 89/9 of September 13, 2001, Recommendations for Transactions Effected by Means of Electronic Payment Instruments, Latvian Information Database (sumber internet). 